\title{
Seasonal variations of outlet glacier terminus position in Greenland
}

\author{
Kristin M. SCHILD, ${ }^{1 *}$ Gordon S. HAMILTON ${ }^{1,2}$ \\ ${ }^{1}$ Climate Change Institute, University of Maine, Orono, ME, USA \\ E-mail: kristin.schild@maine.edu \\ ${ }^{2}$ School of Earth and Climate Sciences, University of Maine, Orono, ME, USA
}

\begin{abstract}
Many of Greenland's marine-terminating outlet glaciers have undergone rapid retreat in the past decade, accompanied by accelerated flow and dynamic thinning. Superimposed on this pattern of retreat, these glaciers undergo seasonal variations in terminus position, corresponding roughly to wintertime advance and summertime retreat. We compiled near-daily time series of terminus position for five of Greenland's largest outlet glaciers (Daugaard Jensen, Kangerdlugssuaq and Helheim glaciers in East Greenland, and Jakobshavn Isbræ and Rink Isbræ in West Greenland) using Moderate Resolution Imaging Spectroradiometer (MODIS) satellite imagery. There are spatial differences in the timing of the onset of seasonal retreat among all the glaciers in our study, as well as variability in terminus behavior for individual glaciers from year to year. We examine whether this spatial and temporal variability is linked to above-freezing air temperatures or high sea surface temperatures, but find no simple relationship. Instead, we hypothesize that terminus geometry (ice thickness, subglacial topography, fjord bathymetry) exerts an important control on the response of marine-terminating glaciers to climate perturbations. Models for predicting outlet glacier response to climate change need to include this complex interaction between geometry and environmental forcing.
\end{abstract}

\section{INTRODUCTION}

A doubling of Greenland's contribution to sea-level rise in the past decade (Rignot and others, 2011) coincided with a widespread retreat (Moon and Joughin, 2008), speed-up (Rignot and Kanagaratnam, 2006) and thinning (Pritchard and others, 2009) of outlet glaciers around the periphery of the ice sheet. These dynamic changes occurred simultaneously with a $1.1^{\circ} \mathrm{C}$ increase in mean summer air temperature (1992-2000 vs 2000-06) observed at widely spaced coastal weather stations (Box and others, 2009) and the accumulation of warm ocean waters of subtropical origin in the adjacent subpolar gyre of the North Atlantic Ocean since the 1990s (Bersch and others, 2007), pointing to a potential link between climate forcing and outlet glacier dynamics. Observations at the ice sheet's three largest outlet glaciers Helheim and Kangerdlugssuaq Glaciers in East Greenland and Jakobshavn Isbræ in West Greenland (Joughin and others, 2004, 2008a,b; Howat and others, 2005, 2007; Luckman and Murray, 2005; Luckman and others, 2006; Stearns and Hamilton, 2007) - reveal a common sequence of events consisting of a modest initial terminus retreat, which caused a subsequent change in force balance and led to acceleration, rapid dynamic thinning and increased calving. While the peak flow speeds have not been sustained for most glaciers around Greenland (Moon and others, 2012), many of them continue to flow faster than they did a decade ago, pointing to the importance of flow dynamics in modulating the ice sheet's contribution to sea-level rise.

Model simulations (Thomas 2004; Nick and others, 2009; Vieli and Nick, 2011) have reproduced the sequence of ice dynamic feedbacks described above, but the trigger for the initial terminus retreat has not been identified conclusively.

*Present address: Department of Earth Sciences, Dartmouth College, Hanover, NH, USA.
Retreat requires an increase in the calving rate (Meier and Post, 1987), so attention has focused on processes that might affect iceberg production. Enhanced fracture propagation at the terminus due to surface meltwater penetrating crevasses (Van der Veen, 2007) can increase iceberg production if the melt season lengthens or becomes more intense. Also potentially important is the presence of a rigid melange of sea ice and icebergs in the fjord in front of the terminus, which might inhibit iceberg calving (Amundson and others, 2010). Mechanical weakening of the melange may lead to increased calving. Atmospheric or oceanic forcing, or a combination, can contribute to each of these processes. Elucidating the interplay of forcing mechanisms and processes that result in dynamic change at Greenland's marine margins is key to understanding how the ice sheet will respond to future changes in climate (Vieli and Nick, 2011).

One pathway to achieving this improved level of understanding is to examine the link between sub-annual changes in terminus position and external climate forcings. Many of Greenland's marine-terminating outlet glaciers undergo an annual cycle in terminus position (e.g. Howat and others, 2008; Seale and others, 2011), providing numerous opportunities to study details of the seasonal transition from advance to retreat. The annual cycle is broadly characterized by advance during the cooler months and retreat during the warmer months, suggesting seasonally driven controls of terminus position. An analysis by Howat and others (2010) did not find any simple correlation between the annual onset of terminus retreat and the onset of above-freezing air temperatures for a group of glaciers in West Greenland, although there was a link between terminus retreat and the increased mobility or clearing of sea-ice melange, consistent with observations elsewhere in Greenland (Sohn and others, 1998; Reeh and others, 2001; Joughin and others, 2008c). One possible interpretation is that the presence of an immobile melange prevents icebergs from calving (e.g. 


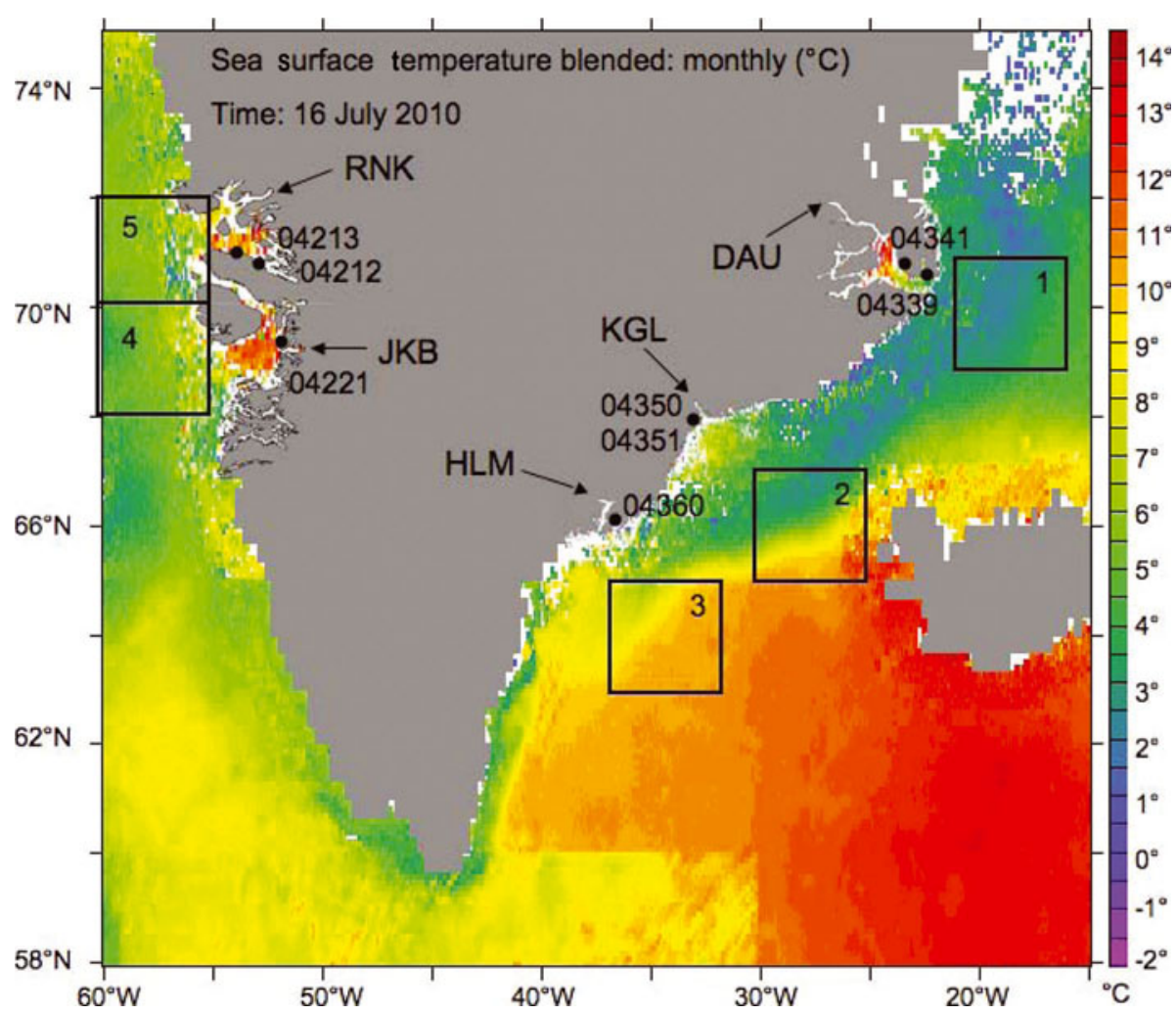

Fig. 1. Map of southern Greenland showing the location of glaciers in this study. Abbreviations are DAU (Daugaard Jensen Glacier), KGL (Kangerdlugssuaq Glacier), HLM (Helheim Glacier), JKB (Jakobshavn Isbræ) and RNK (Rink Isbræ). Black boxes show the regions used to extract sea surface temperature (SST) records, and the black dots show the location and World Meteorological Organization (WMO) ID number for coastal weather stations used for surface air temperature (SAT) records. The background image is average SST for July 2010.

Amundson and others, 2010). Calving resumes when the melange becomes more mobile or is cleared from the fjord. Howat and others (2010) show that the clearing of sea-ice melange is significantly correlated with May sea surface temperatures (SST) but point out that a correlation alone does not establish a causal mechanism with terminus retreat. The terminus and melange might be responding synchronously to a common ocean or atmospheric forcing, or the switch to terminus retreat might be a response to the removal of the melange (Howat and others, 2010). Examining the annual advance/retreat characteristics for a sample of glaciers located in different climatic regions of Greenland might yield additional insights into the controls on the variation in outlet glacier terminus position.

Here we examine 10 years of terminus position behavior for five major outlet glaciers located around the margin of the Greenland ice sheet. Changes in position are mapped using high temporal resolution satellite imagery, and the derived time series are compared with records of air temperature and SST to determine whether these factors are correlated with terminus position change. Our work builds on earlier studies of terminus position changes in Greenland (e.g. Moon and Joughin, 2008; Howat and others, 2010; Box and Decker, 2011; McFadden and others, 2011; Seale and others, 2011; Walsh and others, 2012) by examining high temporal resolution behavior of glaciers in a variety of climatic and dynamic settings.

\section{STUDY AREAS}

We construct high temporal resolution time series of terminus position for five major outlet glaciers distributed around the margin of the Greenland ice sheet (Fig. 1), which are representative of different environmental and dynamic conditions. The glaciers we examine are Daugaard Jensen Glacier (DAU), Kangerdlugssuaq Glacier (KGL), Helheim Glacier (HLM), Jakobshavn Isbræ (JKB) and Rink Isbræ (RNK). All five glaciers are tidewaterterminating and together account for $\sim 28 \%$ of ice discharge from the ice sheet (Rignot and Kanagaratnam, 2006). Kangerdlugssuaq and Helheim Glaciers and Jakobshavn Isbræ all underwent a rapid retreat, acceleration and thinning in the past 15 years (Joughin and others, 2004; Luckman and Murray, 2005; Howat and others, 2007; Stearns and Hamilton, 2007), while Daugaard Jensen Glacier and Rink Isbræ have remained relatively stable (Stearns and others, 2005; Howat and others, 2010). Climatic conditions vary from the relatively mild maritime region of southeast Greenland (HLM) to cooler continental conditions farther north (DAU, RNK). Both Helheim Glacier and Jakobshavn Isbræ are situated in fjords with direct connections to warm ocean waters from branches of the Irminger Current (East and West Greenland currents), while the other glaciers are farther removed from warm ocean currents (Straneo and others, 2012).

\section{DATA SOURCES AND METHODS}

\section{Terminus position}

Calving-front positions for each glacier are derived from approximately daily resolution satellite images. We use images collected by the Moderate Resolution Imaging Spectroradiometer (MODIS) sensors on board the Terra 
and Aqua satellites because they are collected frequently (multiple satellite passes each day) and have adequate spatial resolution $(250 \mathrm{~m})$ for resolving the marine margins of large glaciers. Other satellite sensors collect images with better spatial resolution but usually less frequently (e.g. Howat and others, 2010), which reduces the apparent terminus variability observed at these highly dynamic glaciers and hinders the comparison of terminus position with environmental conditions.

MODIS images for each glacier terminus were obtained from the NASA Rapidfire archive (http://rapidfire.sci.gsfc. nasa.gov) for the period 2001-10. We use the MOD02QKM product, which has a $250 \mathrm{~m}$ spatial resolution and is constructed from MODIS bands $1-2$ in the visible and near-infrared part of the spectrum. Usable images are available for cloud-free days during periods of solar illumination, corresponding to near-daily coverage between 1 May and 31 October each year and approximately weekly coverage for the remainder of the year. In total, $\sim 2715$ usable images were obtained for glaciers in southern Greenland (HLM, KGL, JKB), while for glaciers farther north (DAU, RNK) there were $\sim 1545$ usable images.

All images were reprojected into their respective Universal Transverse Mercator (UTM) coordinate zone on the World Geodetic System 1984 (WGS84) ellipsoid (UTM26 for DAU and KGL; UTM24 for HLM; and UTM22 for JKB and RNK). After enhancing each image for clarity, we manually digitized calving terminus position for each glacier. Automated methods (e.g. Seale and others, 2011) are potentially quicker, but at the cost of inaccurate or inconsistent front determinations (a trained operator is better at discriminating between the true terminus and recently calved icebergs) and smaller datasets (a trained operator can work with images containing partial clouds or insufficient contrast that would be discarded by automated routines), hence our choice of manual digitizing. Each terminus position was digitized according to the procedure described by Moon and Joughin (2008) in which the calving terminus closes a polygon bounded on the sides by parallel lines approximating the lateral margins and at the up-glacier end by an arbitrary line well inland of the minimum observed terminus position. Repeating this procedure for each image yields the change in terminus area with time. We divide the area by polygon width at each terminus position to obtain a width-averaged linear distance of advance/retreat, hereafter referred to simply as advance and retreat. This method allows us to quantify calving-front changes that often occur asymmetrically across the width of the terminus (Howat and others, 2008) and gives a more complete record of terminus change than mapping a linear position to evaluate the distance of advance or retreat along the center line (cf. Seale and others, 2011).

Uncertainties in our time series of terminus positions are likely to arise from three principal sources:

1. The $250 \mathrm{~m}$ pixel resolution of MODIS imagery limits the precision of the derived terminus positions and blurs the boundary between glacier ice and ice melange. To quantify this effect, we compared front positions extracted from MODIS images with those extracted from higher-resolution (15 m) Advanced Spaceborne Thermal Emission and Reflection Radiometer (ASTER) images. The ASTER sensor is carried on board the Terra satellite, meaning images were acquired simultaneously with the MODIS scenes used in our comparison. We compiled 45
ASTER images (approximately six scenes per glacier) and digitized terminus positions using the same procedures described above. The difference between ASTER- and MODIS-derived positions for each glacier on a given day yields an uncertainty of $0.3 \mathrm{~km}$ due to the spatial resolution of MODIS.

2. Manual digitizing might introduce an error because it depends on a combination of operator skill, judgment and consistency. All front positions in our study were digitized by a single operator to avoid any inter-operator bias. To test the repeatability of our manual digitizing, we randomly selected five MODIS images (one per glacier) and digitized them repeatedly over a 4 week period according to the procedures described earlier. Manual digitizing is consistent within $0.2 \mathrm{~km}$, which is satisfactory given the image resolution.

3. Image co-registration errors will introduce offsets in digitized terminus positions. These errors were easily detected when overlaying a glacier's fixed polygon and finding it included valley/fjord walls or was non-parallel to the glacier sides. In the few instances of co-registration error ( $\sim 30$ scenes in total), images were discarded.

Our main interest is understanding the factors that might lead to terminus retreat, so for each glacier we define an annual retreat phase. Determining the duration of the retreat phase is challenging because of the high degree of terminus position variability. The retreat phase can be defined objectively as the elapsed time between maximum and minimum positions of the terminus in one annual cycle but in some cases this definition produces a skewed result. For example, applying this criterion to Kangerdlugssuaq Glacier in 2010 yields a retreat phase of 10 days in duration (time between maximum and minimum terminus positions), whereas the glacier experienced an extremely large retreat early in the season before it quickly readvanced and then continued to retreat for another 88 days. Instead, we define the duration of the retreat season as the time between maximum terminus position and the minimum position prior to subsequent multi-month winter advance. While this definition involves an element of subjectivity in picking the end of the annual retreat, we argue that it provides a better indication of seasonal terminus behavior.

\section{Surface air temperature}

Records of maximum daily surface air temperature (SAT) at the coastal weather station closest to each glacier (Fig. 1) were constructed from hourly measurements obtained from the Danish Meteorological Institute (http://www.dmi.dk) (Cappelen, 2012). Stations are located $85-245 \mathrm{~km}$ from each glacier. Surface temperatures in Greenland are well correlated over these length scales (Box and others, 2009), which gives us confidence that station observations are a good approximation of conditions closer to the glaciers. These data were used to compute the number of positive degree-days (PDDs) in rounded ${ }^{\circ} \mathrm{C}$ above zero (Hock, 2003) as a proxy for surface melt (cf. Hanna and others, 2008; Rignot and others, 2008) in the absence of in situ surface melt observations. Complete records are available during this time period (2001-10) for most coastal weather stations, but several extended data gaps are present for Aputiteq (World Meteorological Organization (WMO) ID 04351), the station closest to Kangerdlugssuaq Glacier. 
The SAT records allow us to determine melt season duration and intensity at each glacier. We define the onset of melting as the start of the first period of five consecutive days when average temperatures exceed $0^{\circ} \mathrm{C}$; similarly, the end of the melt season is defined as the first of five consecutive days when average temperatures fall below $0^{\circ} \mathrm{C}$. Melt season intensity is obtained by summing all PDDs during a melt season. We made no attempt to adjust coastal station temperatures for local conditions at each glacier, for example by using lapse rates to account for elevation differences between stations and glaciers or declining maritime influence in fjords, and instead assume that the coastal records are a good approximation of regional-scale temperatures (coastal stations range in elevation from 10 to $52 \mathrm{~m}$ a.s.I.). Since our analysis is more concerned with relative variations in melt season duration and intensity than absolute PDD values, the adjustment may be unnecessary.

\section{Sea surface temperature}

Monthly time series of SST were compiled for ocean regions adjacent to each glacier using satellite data provided by the CoastWatch program (http://las.pfeg.noaa.gov/oceanWatch) at the US National Oceanic and Atmospheric Administration (NOAA). Our compilations cover the period between July 2002 (date of available data) and December 2010. The SST time series come from a blended product $(11 \mathrm{~km}$ spatial resolution) constructed using weighted observations from the MODIS and Advanced Microwave Scanning Radiometer for Earth Observing System (AMSR-E) sensors on the Aqua spacecraft, the Advanced Very High Resolution Radiometer (AVHRR) on the NOAA's Polar Operational Environmental Satellites (POES) and the Imager on the NOAA's Geostationary Operational Environmental Satellites (GOES).

Deriving accurate SST estimates for coastal areas and narrow fjords is difficult due to the relatively coarse sensor resolution and possible contamination effects from adjacent land surfaces (Pearce and others, 1989) or perennial and seasonal ice cover in fjords. To overcome these difficulties, we extract SST from a $2^{\circ} \times 5^{\circ}$ box over the ice-free ocean sector closest to each fjord opening (Fig. 1) and make the assumption that surface temperatures of the shelf waters are correlated with conditions inside the adjacent fjord. Support for this assumption comes from Sutherland and others (2013) who find that satellite-derived SST is significantly correlated with the upper $\sim 250 \mathrm{~m}$ of shelf water-column temperatures recorded by diving seals off the coast of southeast Greenland, and from Straneo and others (2012) who show that the same near-surface shelf waters are able to penetrate adjacent fjords. We compiled monthly SST averages for each shelf region and express them as anomalies from mean monthly temperatures over the 8.5 years of available data.

\section{RESULTS}

Our analysis of MODIS imagery yields high temporal resolution records of changes in calving terminus position. On average, the terminus position of each glacier is mapped every 2.73 days between the start of March and the end of October each year, which is a modest improvement over the sampling frequency achieved by Seale and others (2011) (4.75 days) who used an automated method to extract terminus position change from MODIS images. These MODIS-based time series are a substantial improvement over seasonal or annual datasets compiled from radar image mosaics (Moon and Joughin, 2008) or intermittently acquired high-resolution optical images (Stearns and others, 2005; Howat and others, 2010; Box and Decker, 2011).

All glaciers in our study undergo an annual cycle of advance and retreat, and some experience multi-year changes in terminus extent. We use the high temporal resolution records to quantify these terminus position changes and examine their timing.

\section{Daugaard Jensen Glacier}

Daugaard Jensen Glacier $\left(71.8^{\circ} \mathrm{N}, 28.7^{\circ} \mathrm{W}\right)$ drains $\sim 3.5 \%$ of the Greenland ice sheet (Rignot and Kanagaratnam, 2006) through a narrow channel located at the head of Scoresby Sund, the largest fjord system in Greenland. Its terminus is $\sim 350 \mathrm{~km}$ from the open ocean (Fig. 1). The main channel of the glacier is confined in a straight-sided fjord $\sim 35 \mathrm{~km}$ long and $\sim 5 \mathrm{~km}$ wide in which the terminus reaches flow speeds of $\sim 11 \mathrm{~m} \mathrm{~d}^{-1}$ (Stearns and others, 2005). Multi-decadal records of front position and ice-flow speed reveal no major changes on Daugaard Jensen Glacier since the 1930s (Stearns and others, 2005; Bevan and others, 2012).

The MODIS time series of terminus positions (Fig. 2) shows distinct seasonal phases of advance and retreat, but with little interannual and intra-seasonal terminus position variations. The retreat phase begins at about the start of May (27 April-12 May) in 2001-05 and 2010 and at about the start of June (28 May-14 June) in 2006 and 2008-09. An anomalously late onset of retreat occurred in 2007 (24 July). On average, the retreat phase lasts 107 days (standard deviation 34 days), with an average loss of $1.34 \mathrm{~km}$ (or the equivalent of $5.92 \mathrm{~km}^{2}$ ) per season (Table 1). The largest retreat occurred in $2004(1.99 \mathrm{~km}$ corresponding to $\left.8.75 \mathrm{~km}^{2}\right)$. Annual retreats generally exceed the subsequent readvances, leading to a modest $(\sim 0.8 \mathrm{~km})$ overall retreat of the terminus during the period of observations.

The air temperature record for Daugaard Jensen Glacier comes from a station at the mouth of Scoresby Sund (Nerlerit Inaat, WMO ID 04341; $245 \mathrm{~km}$ away), and the SST record comes from the shelf offshore of Scoresby Sund (Fig. 1, box 1) ( $300 \mathrm{~km}$ away). The largest observed terminus retreat in 2004 coincided with anomalously high air temperatures and SST (Fig. 2), but establishing a causal link is difficult. The air temperature anomaly occurred in the spring while the SST anomaly occurred after the onset of summer retreat and there is nothing unusual about the onset date or duration of the retreat phase (Table 1). Air temperatures remained anomalously high the following year (2005) while SSTs were anomalously low, although there is nothing unusual in the terminus position record (Fig. 2).

\section{Kangerdlugssuaq Glacier}

Kangerdlugssuaq Glacier $\left(68.5^{\circ} \mathrm{N}, 32.8^{\circ} \mathrm{W}\right)$ in southeast Greenland (Fig. 1) is $\sim 63 \mathrm{~km}$ from the open ocean. It is $\sim 7 \mathrm{~km}$ wide at its terminus and reaches speeds of $\sim 40 \mathrm{~m} \mathrm{~d}^{-1}$ (Stearns and Hamilton, 2007), contributing to a large discharge flux that accounts for $\sim 8 \%$ of the ice sheet's total annual loss (Rignot and Kanagaratnam, 2006). The glacier retreated $8 \mathrm{~km}$, doubled its speed and thinned $\sim 200 \mathrm{~m}$ between 2003 and 2006 (Howat and others, 2007; Stearns and Hamilton, 2007).

The characteristics of the annual advance/retreat cycle of Kangerdlugssuaq Glacier are quite different from those of Daugaard Jensen Glacier. Terminus advance usually commences in winter (Fig. 3) rather than the fall. The earliest 


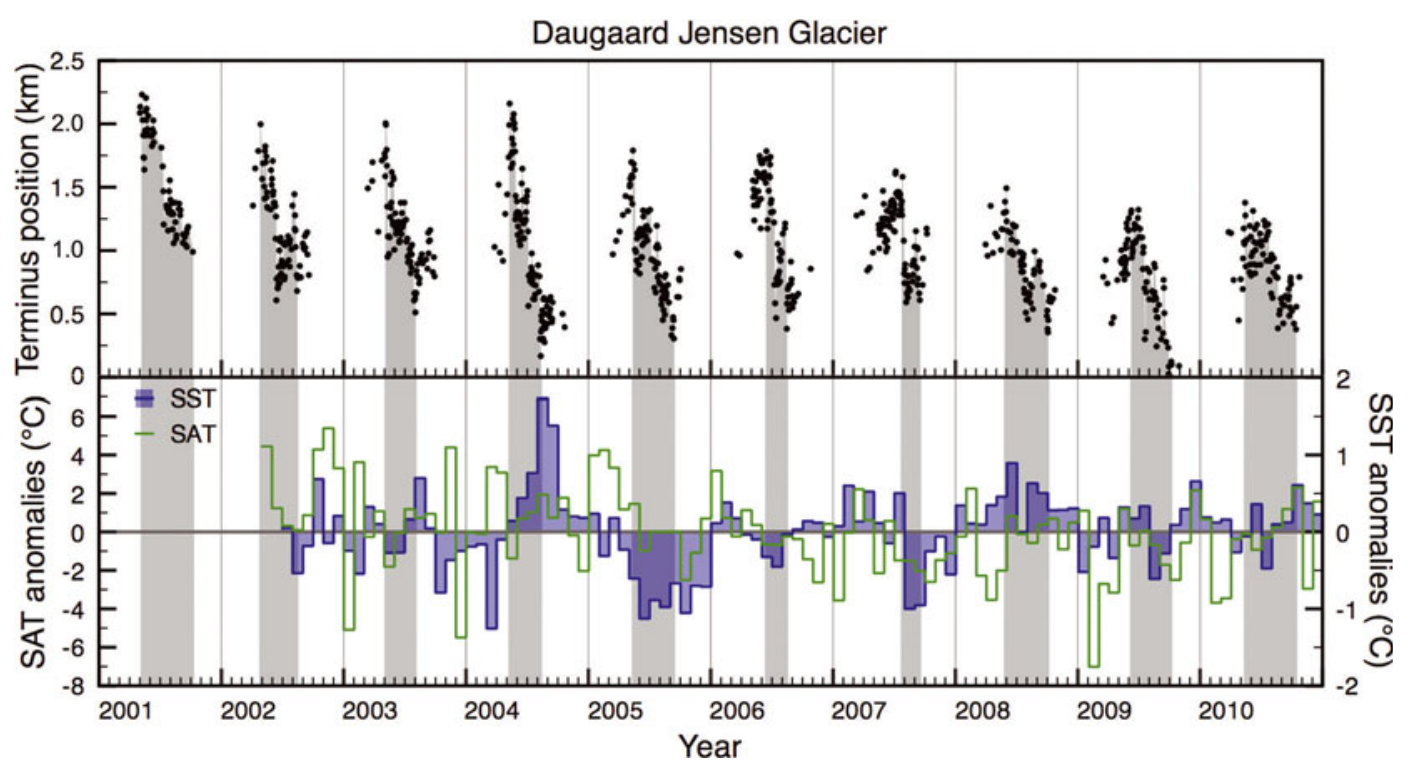

Fig. 2. Daugaard Jensen Glacier: time series of width-averaged terminus change (km, top), monthly mean SAT anomalies $\left({ }^{\circ} \mathrm{C}\right.$, bottom, green) and monthly SST anomalies $\left({ }^{\circ} \mathrm{C}\right.$, bottom, blue) shown as a continuous record with time (year). The gray shaded bars show periods of terminus retreat.

onset date for the retreat phase was 18 June (2007) although retreat commenced as late as 1 August (2008). These observations are consistent with a less frequently sampled record from Joughin and others (2008a). The average duration of the retreat phase is 117 days (standard deviation 53 days) and the average retreat is $3.12 \mathrm{~km}$ (corresponding to $12.16 \mathrm{~km}^{2}$ ) (Table 1). There is an overall terminus retreat of $7.5 \mathrm{~km}$ (corresponding to $\sim 50 \mathrm{~km}^{2}$ ) (Fig. 3) between 2001 and 2010. Retreat is steady between 2001 and 2004, followed by a sudden loss $(\sim 6.5 \mathrm{~km})$ in 2004-05. There is a modest readvance of the terminus $(\sim 5 \mathrm{~km})$ between 2005 and 2008 before steady retreat resumes between 2008 and 2010 (Fig. 3).
The air temperature record for Kangerdlugssuaq Glacier from Aputiteq (WMO ID 04351) is incomplete, so a full analysis is difficult. Available data suggest anomalously high winter air temperatures in 2004/05 coincided with the maximum terminus retreat of $\sim 6.5 \mathrm{~km}$ (Fig. 3). Observations from other coastal stations in southeast Greenland (Hanna and others, 2008) show that regional air temperatures were above average at this time and SSTs (derived for the region shown in Fig. 1, box 2) were also much higher than average in the latter half of 2004 (Fig. 3). These conditions may have contributed to an unusually late formation of sea ice in the fjord during the 2004/05 winter (Seale and others, 2011) and possibly a more mobile melange that enabled the calving

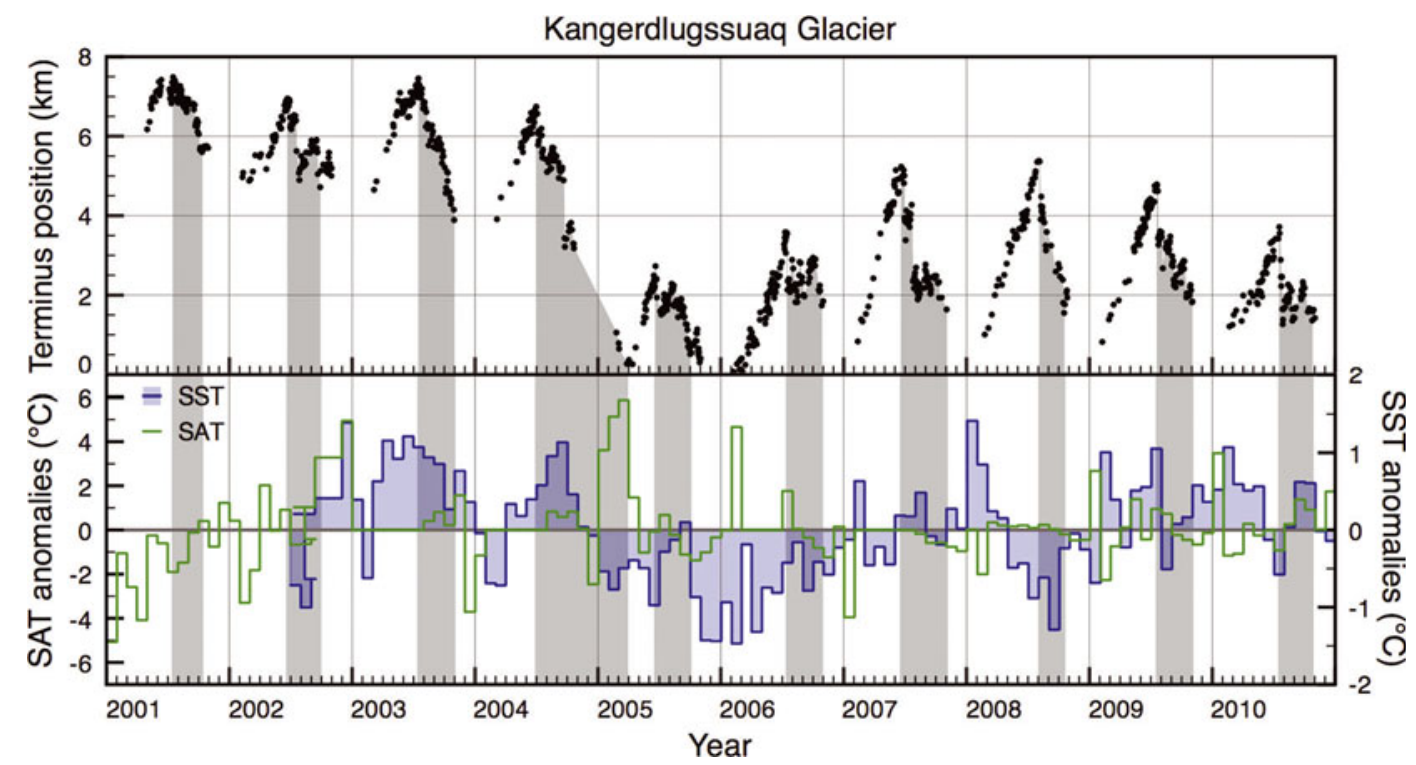

Fig. 3. Kangerdlugssuaq Glacier: time series of width-averaged terminus change ( $\mathrm{km}$, top), monthly mean SAT anomalies $\left({ }^{\circ} \mathrm{C}\right.$, bottom, green) and monthly SST anomalies $\left({ }^{\circ} \mathrm{C}\right.$, bottom, blue) shown as a continuous record with time (year). The gray shaded bars show periods of terminus retreat. Gaps in the SAT anomaly record are due to missing air temperature data from Aputiteq (January-July 2003, January-July 2004, March-July 2006, February-July 2007). 
Table 1. Metrics describing seasonal retreat for all five glaciers in our study. Column 2 shows the total area lost during each retreat season, while column 3 expresses retreat as a linear distance (area loss divided by terminus width). The asterisk denotes a retreat season that continued into the subsequent calendar year

\begin{tabular}{|c|c|c|c|c|c|}
\hline \multirow[t]{2}{*}{ Year } & $\begin{array}{l}\text { Terminus } \\
\text { area loss }\end{array}$ & Retreat & $\begin{array}{l}\text { Start of } \\
\text { retreat }\end{array}$ & $\begin{array}{l}\text { End of } \\
\text { retreat }\end{array}$ & $\begin{array}{l}\text { Retreat } \\
\text { duration }\end{array}$ \\
\hline & $\mathrm{km}^{2}$ & $\mathrm{~km}$ & day of year & day of year & days \\
\hline
\end{tabular}

Daugaard Jensen Glacier

\begin{tabular}{|c|c|c|c|c|c|}
\hline 2001 & 5.45 & 1.24 & 128 & 280 & 152 \\
\hline 2002 & 6.10 & 1.38 & 117 & 226 & 109 \\
\hline 2003 & 6.56 & 1.49 & 125 & 214 & 89 \\
\hline 2004 & 8.75 & 1.99 & 130 & 223 & 93 \\
\hline 2005 & 6.52 & 1.48 & 132 & 254 & 122 \\
\hline 2006 & 6.16 & 1.40 & 165 & 226 & 61 \\
\hline 2007 & 4.54 & 1.03 & 205 & 257 & 52 \\
\hline 2008 & 5.00 & 1.13 & 149 & 273 & 124 \\
\hline 2009 & 5.80 & 1.32 & 155 & 273 & 118 \\
\hline 2010 & 4.39 & 0.99 & 128 & 280 & 152 \\
\hline Average & 5.92 & 1.34 & 143 & 251 & 107 \\
\hline \multicolumn{6}{|c|}{ Kangerdlugssuaq Glacier } \\
\hline 2001 & 7.34 & 1.88 & 198 & 284 & 86 \\
\hline 2002 & 8.68 & 2.23 & 173 & 270 & 97 \\
\hline 2003 & 13.87 & 3.56 & 197 & 303 & 106 \\
\hline 2004 & 25.17 & 6.45 & 182 & $85^{*}$ & 269 \\
\hline 2005 & 9.43 & 2.41 & 170 & 273 & 103 \\
\hline 2006 & 7.17 & 1.84 & 196 & 299 & 103 \\
\hline 2007 & 13.99 & 3.59 & 169 & 304 & 135 \\
\hline 2008 & 14.90 & 3.82 & 214 & 287 & 73 \\
\hline 2009 & 11.54 & 2.96 & 196 & 300 & 104 \\
\hline 2010 & 9.53 & 2.44 & 193 & 291 & 98 \\
\hline Average & 12.16 & 3.12 & 189 & 270 & 117 \\
\hline \multicolumn{6}{|c|}{ Helheim Glacier } \\
\hline 2001 & 4.49 & 0.90 & 163 & 254 & 91 \\
\hline 2002 & 8.02 & 1.60 & 94 & 227 & 133 \\
\hline 2003 & 11.03 & 2.20 & 117 & 293 & 176 \\
\hline 2004 & 12.25 & 2.45 & 110 & 270 & 160 \\
\hline 2005 & 13.72 & 2.74 & 92 & 234 & 142 \\
\hline 2006 & 14.48 & 2.89 & 153 & 260 & 107 \\
\hline 2007 & 10.55 & 2.11 & 171 & 239 & 68 \\
\hline 2008 & 13.97 & 2.79 & 193 & 262 & 69 \\
\hline 2009 & 7.95 & 1.59 & 88 & 241 & 153 \\
\hline 2010 & 13.40 & 2.68 & 153 & 258 & 105 \\
\hline Average & 10.99 & 2.20 & 133 & 254 & 120 \\
\hline \multicolumn{6}{|c|}{ Jakobshavn Isbræ } \\
\hline 2001 & 32.77 & 3.95 & 114 & 238 & 124 \\
\hline 2002 & 45.43 & 5.47 & 74 & 270 & 196 \\
\hline 2003 & 55.31 & 6.66 & 67 & 255 & 188 \\
\hline 2004 & 60.59 & 7.30 & 82 & 265 & 183 \\
\hline 2005 & 46.48 & 5.60 & 121 & 228 & 107 \\
\hline 2006 & 41.64 & 4.99 & 62 & 263 & 201 \\
\hline 2007 & 51.78 & 6.24 & 75 & 221 & 146 \\
\hline 2008 & 51.67 & 6.22 & 80 & 230 & 150 \\
\hline 2009 & 53.92 & 6.49 & 98 & 226 & 128 \\
\hline 2010 & 20.45 & 2.46 & 45 & 202 & 157 \\
\hline Average & 46.00 & 5.54 & 82 & 240 & 158 \\
\hline \multicolumn{6}{|c|}{ Rink Isbræ } \\
\hline 2001 & 3.80 & 0.70 & 143 & 292 & 149 \\
\hline 2002 & 2.76 & 0.51 & 151 & 252 & 101 \\
\hline 2003 & 7.38 & 1.36 & 147 & 251 & 104 \\
\hline 2004 & 4.85 & 0.90 & 140 & 263 & 123 \\
\hline 2005 & 5.78 & 1.07 & 133 & 248 & 115 \\
\hline 2006 & 5.91 & 1.09 & 165 & 262 & 97 \\
\hline 2007 & 6.04 & 1.12 & 134 & 236 & 102 \\
\hline 2008 & 6.47 & 1.20 & 125 & 297 & 172 \\
\hline 2009 & 5.01 & 0.92 & 180 & 255 & 75 \\
\hline 2010 & 4.17 & 0.77 & 162 & 274 & 112 \\
\hline Average & 5.22 & 0.96 & 148 & 263 & 115 \\
\hline
\end{tabular}

front to continue retreating well into 2005 (26 March). Lower than average SATs and SSTs in 2005 and 2006 coincided with a net readvance of the terminus.

\section{Helheim Glacier}

Helheim Glacier $\left(66.3^{\circ} \mathrm{N}, 38^{\circ} \mathrm{W}\right)$ in southeast Greenland (Fig. 1) drains $\sim 7 \%$ of the ice sheet (Rignot and Kanagaratnam, 2006) through a $\sim 6 \mathrm{~km}$ wide channel in which speeds reach $\sim 30 \mathrm{~m} \mathrm{~d}^{-1}$ (Nettles and others, 2008). It terminates in Sermilik Fjord $\sim 100 \mathrm{~km}$ from the open ocean. The glacier retreated, accelerated and thinned between 2002 and 2005 (Howat and others, 2007; Stearns and Hamilton, 2007). Flow speeds have decelerated since 2005 (Moon and others, 2012) but remain above pre-2002 levels.

The onset of seasonal retreat varies considerably during our time series, beginning as early as 29 March (day 88, 2009) and as late as 11 July (day 193, 2008). The duration is equally as variable, with retreat lasting between 68 days (2007) and 176 days (2003) and an average of 120 days (standard deviation 36 days) (Table 1). There is no clear pattern in the timing or duration of retreat phases and the amount of terminus retreat each year (Table 1).

Our time series shows a retreat of the minimum seasonal terminus position between 2001 and 2005 (Fig. 4) as the glacier moved steadily up-fjord (cf. Howat and others, 2005, 2008; Joughin and others, 2008a). The 2001 retreat phase is characterized by episodes of short retreats $(\sim 0.5 \mathrm{~km}$, corresponding to $\sim 4 \mathrm{~km}^{2}$ ) quickly followed by advances lasting 1-6 days. A similar pattern is observed in 2002, but with a more pronounced retreat phase beginning in early April and lasting until mid-August (Fig. 4). Pronounced retreat continues between 2003 and 2005, while the onset of advance begins earlier each year (20 October in 2003 and 22 August in 2005). The glacier reached its minimum terminus position in the MODIS record in 2005 (Fig. 4), amounting to $\sim 8 \mathrm{~km}$ of retreat since 2001. Much of the terminus region was regained during the 2005-06 advance phase ( $\sim 6 \mathrm{~km})$.

Air temperature data were collected in Tasiilaq (WMO ID 04360), which is $\sim 86 \mathrm{~km}$ from the glacier. The SST record comes from farther offshore (Fig. 1, box 3) due to the persistent presence of near-coastal sea ice, which prevents the extraction of reliable temperature estimates from satellite images. The up-fjord retreat of the terminus between 2003 and 2005 occurs during a period of above-average SATs and SSTs (Howat and others, 2008), with high SAT anomalies for the 3 months prior to retreat onset in 2004 and 2005 and for the 7 months prior to retreat onset in 2003 (Fig. 4). Anomalously low SATs and SSTs in 2005-06 are associated with terminus readvance (Fig. 4).

\section{Jakobshavn Isbræ}

Jakobshavn Isbræ $\left(69^{\circ} \mathrm{N}, 50^{\circ} \mathrm{W}\right)$ is located on the central west coast of Greenland (Fig. 1) and is responsible for discharging $\sim 7 \%$ of the ice sheet's annual mass flux (Rignot and Kanagaratnam, 2006). Its terminus is $\sim 8 \mathrm{~km}$ wide and flows at speeds of $\sim 45 \mathrm{~m} \mathrm{~d}^{-1}$ (Dietrich and others, 2007). Of the five glaciers in this study, Jakobshavn Isbræ had the largest annual terminus change, with an average distance between maximum and minimum positions of $5.5 \mathrm{~km}$ (corresponding to $\sim 46 \mathrm{~km}^{2}$ ). The largest retreat occurred in 2004 (Fig. 5; Table 1).

Jakobshavn Isbræ has the earliest onset of retreat of any glacier in our study. The earliest observed start to the retreat phase was in 2010 (14 February, day 45), but this might be 


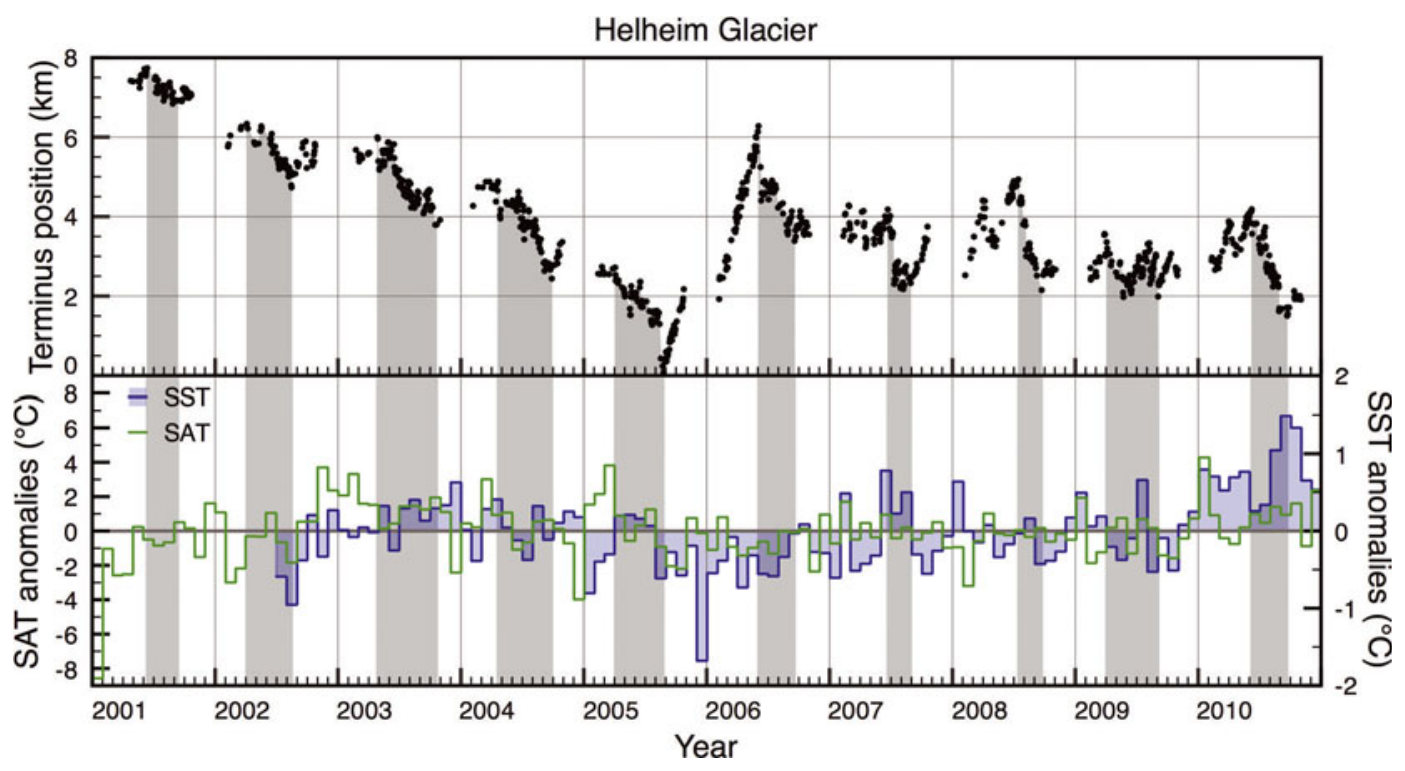

Fig. 4. Helheim Glacier: time series of width-averaged terminus change $\left(\mathrm{km}\right.$, top), monthly mean SAT anomalies $\left({ }^{\circ} \mathrm{C}\right.$, bottom, green) and monthly SST anomalies $\left({ }^{\circ} \mathrm{C}\right.$, bottom, blue) shown as a continuous record with time (year). The gray shaded bars show periods of terminus retreat.

artificially early because of the lack of a substantial winter advance phase during the 2009/10 winter. For all other years, the earliest observed onset of retreat was in 2006 (3 March, day 62) and the latest was in 2005 (1 May, day 121) (Fig. 5). On average, the onset of retreat occurred on 23 March (day 82, Table 1). The transition to readvance occurred as early as 21 July (day 202, 2010) and as late as 27 September (day 270, 2002) (Table 1), with an average onset of readvance of 28 August (day 240). Retreat phases varied in duration from as few as 107 days (2005) to as many as 201 days (2006), with an average of 158 days (standard deviation 33 days) (Table 1). Unlike Helheim and Kangerdlugssuaq Glaciers, where the interannual terminus positions continually retreated up-fjord until 2005 and then began to advance, Jakobshavn Isbræ remains on a progressive retreat, with its minimum position moving farther upfjord each season (Fig. 5). We note, however, that the rate of retreat has slowed since 2004.

Surface air temperatures recorded at Ilulissat (WMO ID 04221) show that the largest anomalies (positive and negative) tended to occur during the late winter months of January-March. The largest positive SAT and SST anomalies occurred in 2010 (Fig. 5), which coincided with a lack of wintertime (2009/10) terminus advance and the smallest observed range in annual terminus position. Over the course of the record, a net retreat of the Jakobshavn terminus was accompanied by an increase (decrease) in the frequency of positive (negative) SST anomalies (Fig. 5).

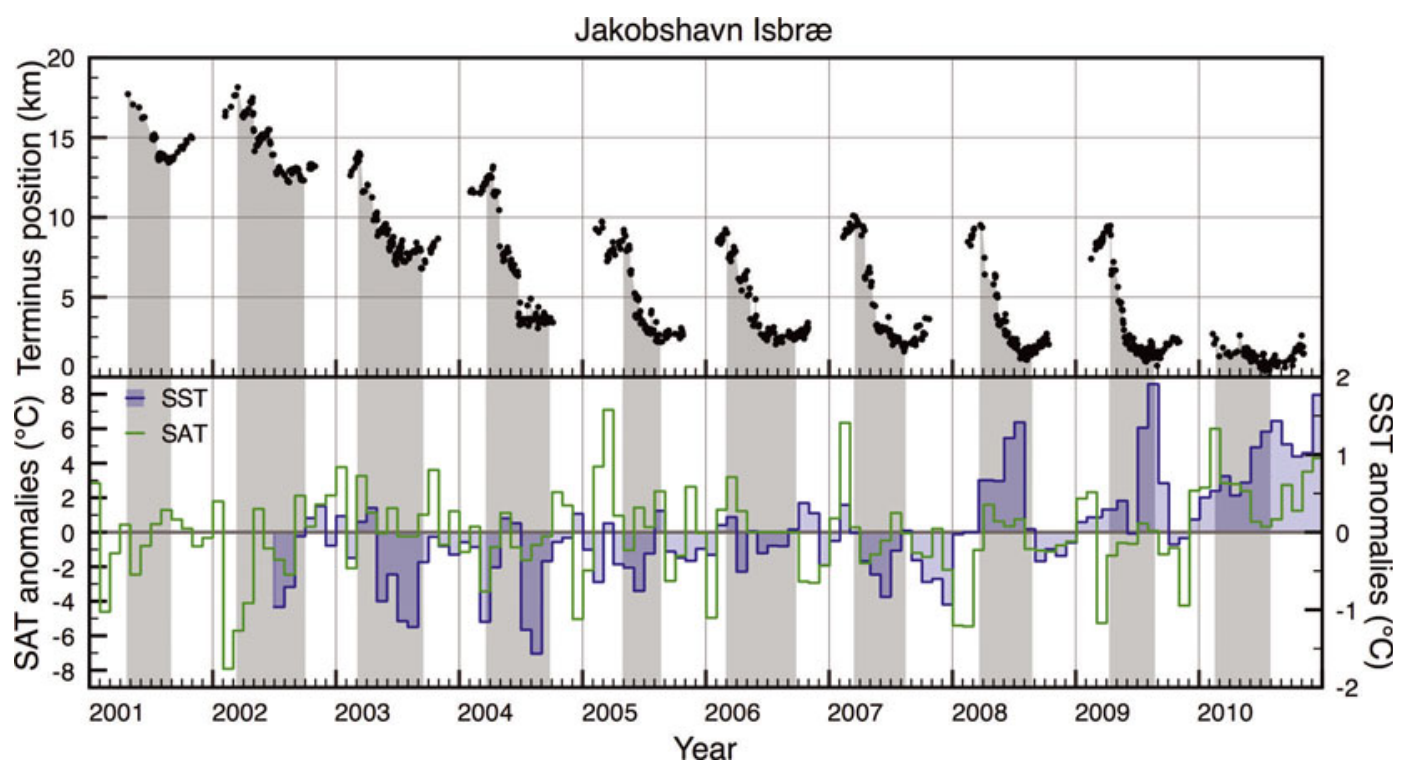

Fig. 5. Jakobshavn Isbræ: time series of width-averaged terminus change $\left(\mathrm{km}\right.$, top), monthly mean SAT anomalies $\left({ }^{\circ} \mathrm{C}\right.$, bottom, green) and monthly SST anomalies $\left({ }^{\circ} \mathrm{C}\right.$, bottom, blue) shown as a continuous record with time (year). The gray shaded bars show periods of terminus retreat. 


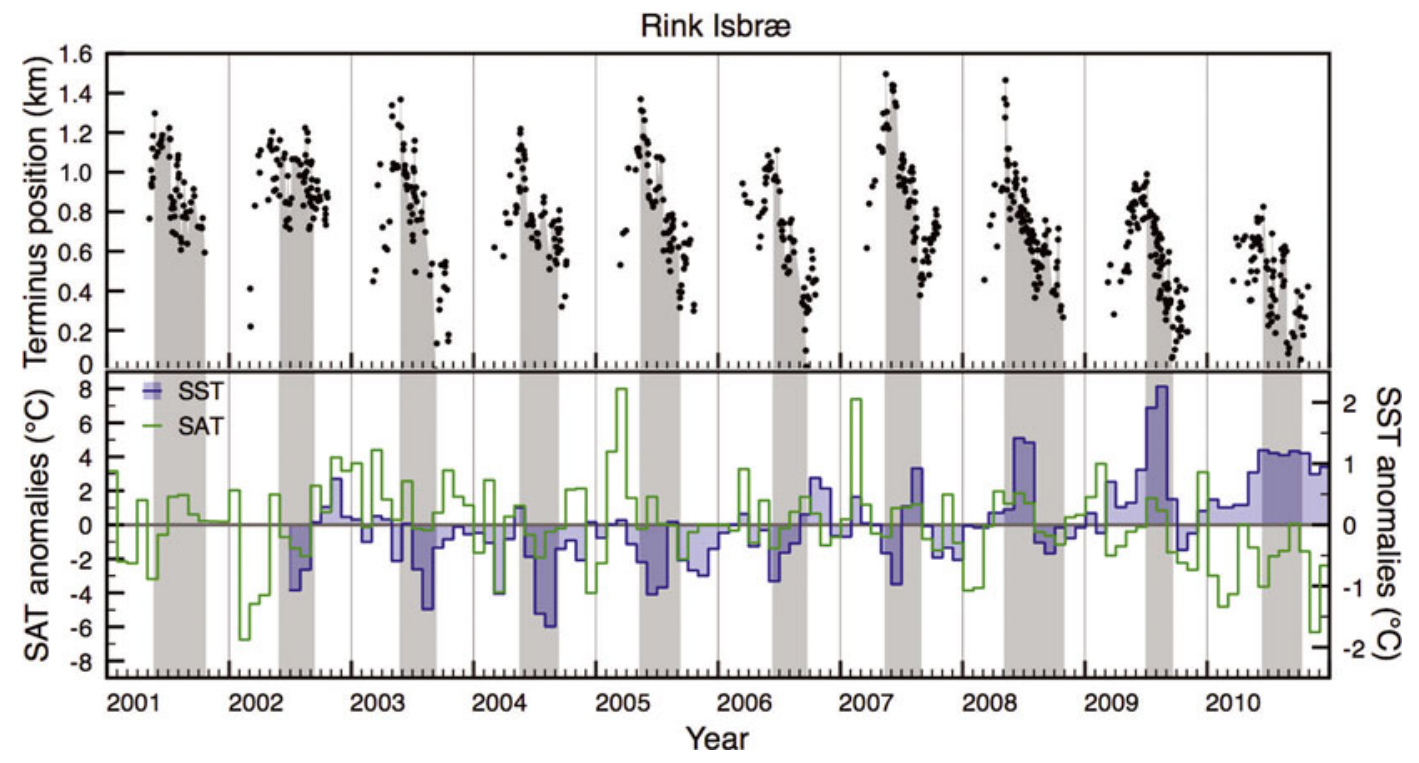

Fig. 6. Rink Isbræ: time series of width-averaged terminus change ( $\mathrm{km}$, top), monthly mean SAT anomalies $\left({ }^{\circ} \mathrm{C}\right.$, bottom, green) and monthly SST anomalies $\left({ }^{\circ} \mathrm{C}\right.$, bottom, blue) shown as a continuous record with time (year). The gray shaded bars show periods of terminus retreat.

\section{Rink Isbræ}

Rink Isbræ $\left(71.7^{\circ} \mathrm{N}, 51.6^{\circ} \mathrm{W}\right)$ is located on the west coast of Greenland and drains $\sim 3.5 \%$ of the Greenland ice sheet (Rignot and Kanagaratnam, 2006) through a $5.5 \mathrm{~km}$ wide fjord located $\sim 109 \mathrm{~km}$ from the ocean. It is the only glacier in our study that does not have a persistent ice melange in the fjord during summer. There have been no major changes in ice dynamics or geometry in recent decades (Howat and others, 2010)

Our time series shows a modest cycle $(\sim 1 \mathrm{~km})$ in seasonal terminus position (Fig. 6), but not much interannual variability except for a small retreat of the seasonal maximum positions in 2009 and 2010. Between 2001 and 2010 , the terminus retreated an average of $0.96 \mathrm{~km} \mathrm{a}^{-1}$ (corresponding to $5.2 \mathrm{~km}^{2} \mathrm{a}^{-1}$ ), with the largest retreat occurring in $2003\left(1.36 \mathrm{~km}\right.$, corresponding to $7.38 \mathrm{~km}^{2}$ ) (Table 1). The onset of the retreat phase commenced as early as 4 May (day 125, 2008) and as late as 29 June (day 180, 2009) (Table 1). The resumption of terminus advance varied between 24 August (day 236, 2007) and 23 October (day $297,2008)$. Duration of the retreat phase ranged from 75 days (2009) to 149 days (2001), with an average duration of 115 days (standard deviation 28 days) (Table 1 ).

The two greatest positive anomalies in the air temperature record from Qaarsut (WMO ID 04213) occurred in late winter (March 2005 and February 2007) during periods of terminus advance $(\sim 1.0-1.5 \mathrm{~km})$. Conversely, the smallest terminus advance $(\sim 0.8 \mathrm{~km})$ took place during a period of anomalously low air temperatures in early 2010 (Fig. 6). The tendency for SST anomalies to be positive towards the end of the record may explain a small net retreat in the terminus position of Rink Isbræ between 2008 and 2010 (Fig. 6).

\section{DISCUSSION}

Our results showing annual cycles and multi-year trends in terminus position are largely consistent with other studies (e.g. Joughin and others, 2008a; Box and Decker, 2011; Seale and others, 2011). Minor differences are mostly due to different sampling methodologies. For example, Box and
Decker (2011) tend to slightly underestimate annual and decadal (2001-10) terminus position changes relative to our results because their study was based on minimum positions mapped during a fixed period each year (mid-August to late September) which, according to our analysis, is not necessarily when annual minimum positions occur. Seale and others (2011) report slightly larger values for mean annual terminus retreat at Helheim and Kangerdlugssuaq Glaciers $(2.27$ and $3.44 \mathrm{~km}$, respectively, versus 2.20 and $2.83 \mathrm{~km}$, respectively, in this study). We attribute this difference to Seale and others (2011) observing linear change at the center line (where the largest changes tend to occur) while we report average retreat across the full width of the terminus.

We find a strong correlation $(r=0.95)$ between glacier width and the amount of calving terminus retreat. A similar correlation was noted by Seale and others (2011) for a larger population of 32 glaciers, although a separate analysis of 59 glaciers by McFadden and others (2011) was inconclusive. Closer inspection of figure 8 in McFadden and others (2011) suggests that two outliers (short retreats of very wide glaciers) may have masked a stronger width-dependent relationship in the rest of their population. If this is the case, all three studies probably point towards the importance of lateral drag in modulating the stability of tidewater glacier terminus positions (cf. Echelmeyer and others, 1994).

We use our time series of terminus positions to determine whether there are spatial patterns in the onset of annual retreat phases that might provide insight into environmental forcing factors. For example, we can test whether glaciers in warmer climates or adjacent to warmer ocean waters have an earlier onset of retreat. This might be expected because above-freezing air temperatures will generate meltwater, which can accumulate in near-terminus crevasses and promote rift formation and calving by hydrofracture (Van der Veen, 2007). Alternatively, high air temperatures or the arrival of warm near-surface ocean waters may weaken a rigid melange and result in increased calving (Joughin and others, 2008a; Howat and others, 2010). Instead, our observations do not provide strong evidence to support a link between temperature and terminus position change 
SAT

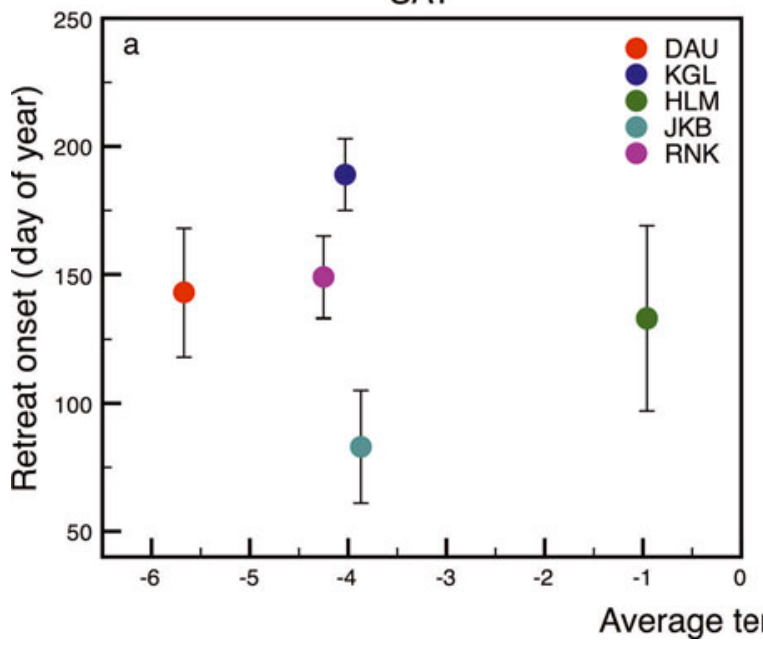

SST

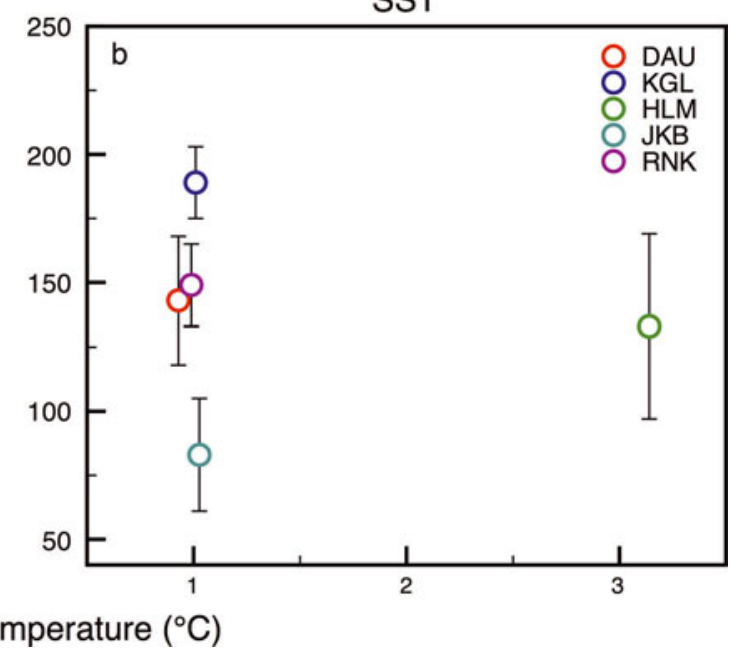

Fig. 7. Onset date of terminus retreat plotted against (a) mean annual SAT and (b) mean annual SST. Abbreviations are as in Figure 1. DAU SAT record was from 1980 to 2010 at Nerlerit Inaat (WMO ID 04339), KGL from 1980 to 2010 at two Aputiteq stations (WMO ID 04350 and 04351), HLM from 1980 to 2010 at Tasiilaq (WMO ID 04360), JKB from 1991 to 2010 at Ilulissat (WMO ID 04221) and RNK from 1961 to 1989 at Uumannaq (WMO ID 04212). Vertical bars show one standard deviation of onset date calculated in Table 1.

(Fig. 7). Plotting the average dates for the onset of retreat against 30 year mean annual SAT does not yield a robust relationship (Fig. 7a), possibly suggesting a weak dependence of terminus position change on high temperatures alone. For example, Kangerdlugssuaq Glacier begins its seasonal retreat, on average, 107 days later than Jakobshavn Isbræ (Table 1), despite both glaciers having similar mean annual SAT (Fig. 7a). Likewise for mean annual SST, we found that glaciers adjacent to relatively warm near-surface ocean waters did not undergo earlier onsets of retreat (Fig. 7b).

To further examine the possible influence of air temperature on retreat, we compared melt season intensity (summed total of PDDs) with the seasonal retreat for each glacier (Fig. 8). There is no statistically significant correlation between the amount of terminus retreat and melt season intensity for the sample population as a whole, although the values for individual glaciers appear to cluster (Fig. 8), perhaps pointing to a variable response to air temperature specific to each glacier. Kangerdlugssuaq Glacier alone appears to have a strong positive linear relationship $(r=0.93)$ between summed PDDs and the amount of seasonal retreat (Fig. 8), although a relatively small number of annual samples due to gaps in the Aputiteq air temperature record makes it challenging to draw meaningful conclusions. The relationship is less clear for other glaciers. Daugaard Jensen Glacier and Rink Isbræ show little interannual variation in the amount of retreat, although some melt seasons are clearly more intense than others (Fig. 8). Neither Helheim Glacier nor Jakobshavn Isbræ shows any statistically significant relationship between melt intensity and terminus retreat $(r \approx 0.09)$, probably because of strong outliers in some years (Fig. 8).

The length of time over which a terminus retreats is not closely tied to melt season duration (Fig. 9). In other words, long (or short) periods of retreat are not necessarily associated with long (or short) melt seasons. Joughin and others (2008b) speculated that the proportion of the year during which melting occurs might be linked to the amount of calving and there are hints of such a qualitative relationship at Helheim Glacier and Jakobshavn Isbræ. For example, the longest-lasting annual retreats for both glaciers occurred during their longest melt seasons (Fig. 9). However, their shortest periods of annual retreat did not occur during especially short melt seasons and there is no conclusive relationship between melt season duration and retreat duration for other glaciers in the study (Fig. 9).

For all but one glacier in our study, the annual onset of terminus retreat lags the start of the melt season by anywhere from 4 to 101 days (Fig. 10a). Jakobshavn Isbræ is a consistent exception, with the onset of its annual terminus retreat preceding the start of the melt season by 3-70 days. This early onset was previously noted by Joughin and others (2008b) who attributed it to warming late-winter SST and the weakening of sea-ice melange in front of the terminus. Our Jakobshavn dataset provides some support for this hypothesis in that years with the early onsets of retreat (2003,2006, $2007,2010)$ correspond to years with anomalously warm wintertime SST (Fig. 5). These warmer than average surface waters might have eroded the underside of the melange, perhaps weakening it. However, these same winters also had above-average, though not necessarily above-freezing, air

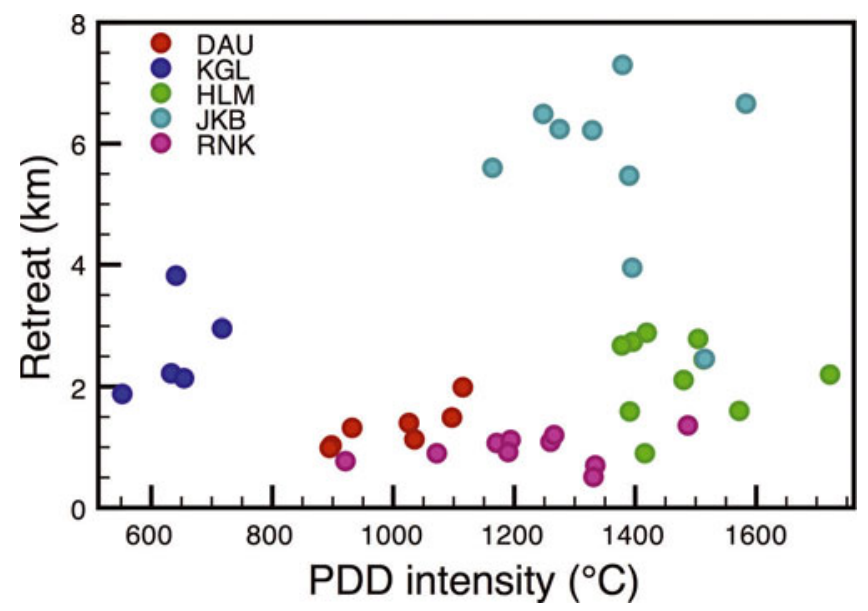

Fig. 8. Positive degree day (PDD) intensity for each melt season plotted against the width-normalized retreat for each glacier. Abbreviations are as in Figure 1. 

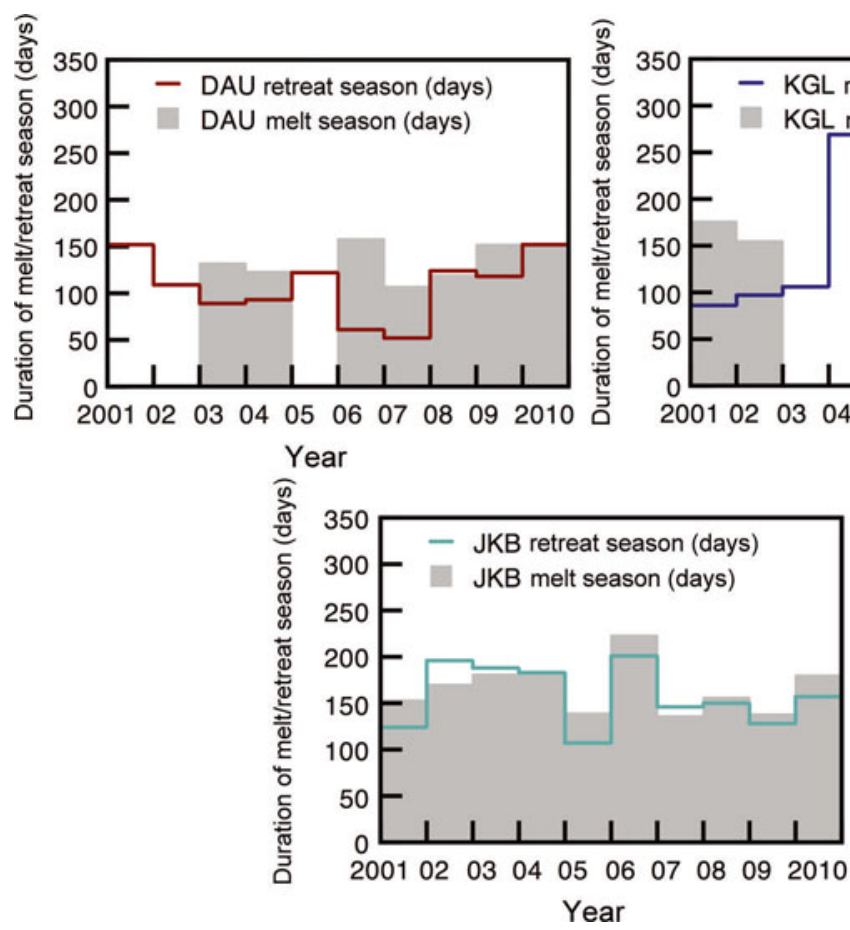
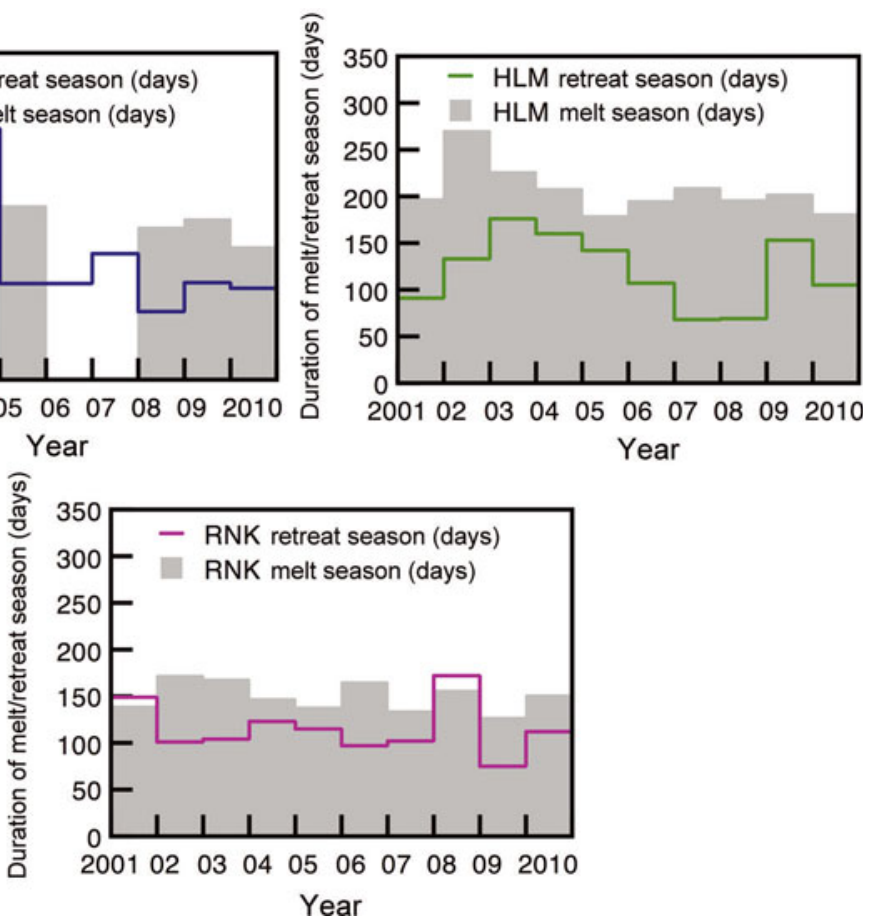

Fig. 9. Duration of the melt season as derived from PDDs compared with the duration of the retreat season derived from the MODIS terminus position time series for each glacier. Abbreviations are as in Figure 1. Kangerdlugssuaq Glacier (Aputiteq) was missing early-season air temperature data for 2003, 2004, 2006 and 2007; therefore, the duration of the melt season could not be calculated in those years.

temperatures (Fig. 5), making it difficult to tease out any mechanistic link. Likewise, for other glaciers there is no consistent relationship between the early or late onsets of seasonal retreat and seasonal SST and SAT anomalies (Figs 26 and 10). The lack of a clear link with SST is perhaps not surprising given that melange rigidity is likely affected not only by thermal forcing, but by mechanical forcing such as strong wind events (e.g. Walter and others, 2012).

In general, glaciers switch from retreat to advance prior to the end of the melt season (Fig. 10b). Kangerdlugssuaq Glacier was the most frequent exception to this pattern. Its late switch from retreat to advance may be a consequence of the glacier's latest on-average onset of seasonal retreat (day 189; Table 1).
The glaciers in our study fall into two broad categories. One category consists of glaciers that can be defined as stable (Daugaard Jensen Glacier and Rink Isbræ). The mean terminus positions of these glaciers do not change much from year to year and there is little variation in the magnitudes of their annual terminus retreat. These characteristics are indicative of glaciers in which mass fluxes are approximately in balance with their geometric settings (width, fjord bathymetry; e.g. Post and others, 2011). The second category consists of glaciers that have undergone multi-year terminus retreats (Kangerdlugssuaq and Helheim Glaciers, Jakobshavn Isbræ). These glaciers show large yearto-year variations in terminus behavior superimposed on longer-term patterns of retreat. Longer-term multi-year
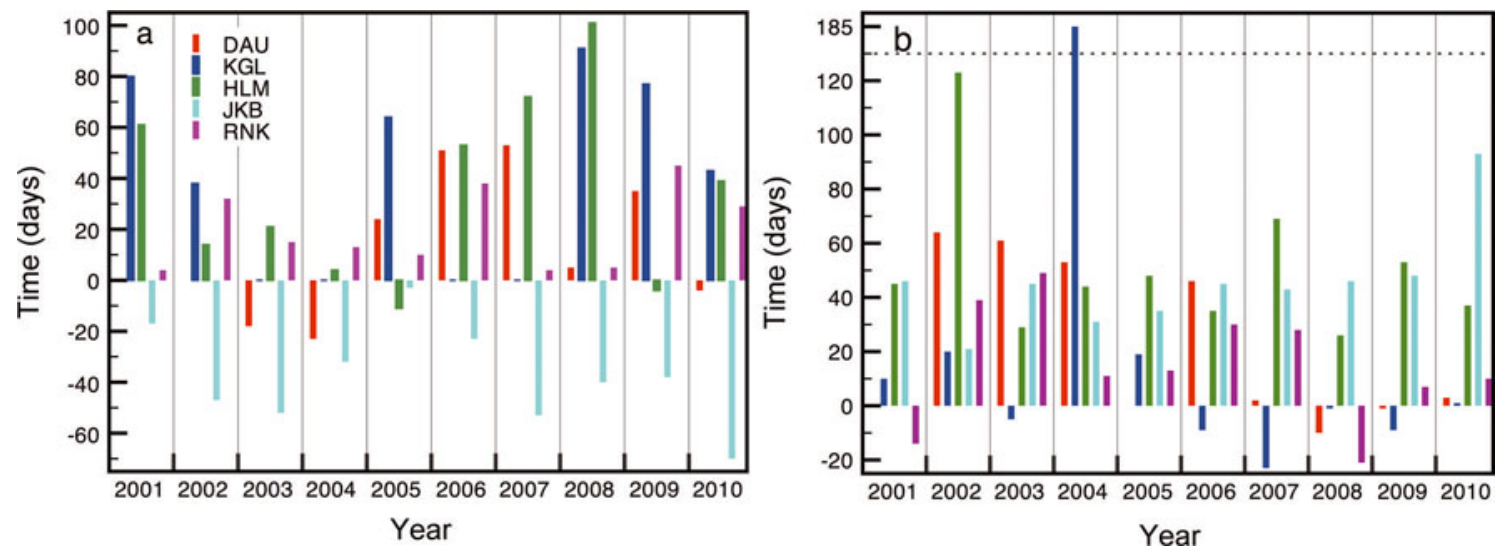

Fig. 10. Bar graphs showing (a) the time (days) between the start of the PDD-derived melt season and terminus retreat and (b) the time (days) between the end of retreat and the PDD-derived melt season. A negative number indicates that retreat began before the melt season (a) or lasted beyond the melt season (b). Abbreviations are as in Figure 1. Kangerdlugssuaq Glacier (Aputiteq) was missing early-season air temperature data for 2003, 2004, 2006 and 2007; therefore, the time between the start of the melt season and the onset of retreat could not be calculated for these years. 
variations are indicative of continued adjustments to glacier geometry following changes in mass fluxes at the terminus (Meier and Post, 1987).

Much of the unexplained spatial and temporal variability in our observations may be a function of the bedrock configuration of each glacier (Nick and Oerlemans, 2006; Vieli and Nick, 2011). Calving retreat appears to be linked to the height of a terminus above flotation (Amundson and others, 2010). The buoyancy conditions of a terminus depend on its geometry (ice thickness, gradients in ice surface slope, bedrock topography and fjord bathymetry), such that reverse bed slopes behind the terminus and shallow surface gradients promote calving of large areas of the terminus once it has been thinned to near-flotation (McFadden and others, 2011). For the glaciers in our sample, which are undergoing multiyear calving-front retreat, their near-terminus geometry will vary on a year-by-year basis. Owing to variations in geometry, a different amount of air and/or ocean temperature forcing will be required each year to bring a terminus close to flotation and initiate calving. This uniqueness makes it difficult to parameterize a set of forcing factors with wide applicability to tidewater outlet glaciers.

\section{SUMMARY}

We constructed high temporal resolution time series of calving terminus position for five of Greenland's largest outlet glaciers (Daugaard Jensen, Kangerdlugssuaq and Helheim glaciers in East Greenland, and Jakobshavn Isbræ and Rink Isbræ in West Greenland) using MODIS satellite imagery for the period 2001-10. The time series for each glacier contains an annual cycle in terminus position, corresponding roughly to wintertime advance and summertime retreat. There are spatial differences in the timing of the onset of retreat among all the glaciers in our study, as well as variability in terminus behavior for individual glaciers from year to year. The spatial variability does not appear to have a simple link to mean annual surface air temperature. For example, Jakobshavn Isbræ consistently has the earliest average onset of retreat in our study (23 March, day 82) despite having a similar mean annual temperature to Kangerdlugssuaq Glacier which starts retreating, on average, 107 days later. We also find that interannual variations in terminus retreat for individual glaciers are poorly explained by melt season duration or intensity.

The switch from advance to retreat for most glaciers occurs 4-101 days after the onset of seasonal melting. Only Jakobshavn Isbræ consistently starts retreating before the onset of melting, which might be related to the occurrence of anomalously warm surface ocean waters weakening the fjord melange and a subsequent increase in calving rate (Joughin and others, 2008b). This relationship was not evident for other glaciers in our study.

The difficulty in establishing clear links between seasonal retreat and air and sea surface temperature conditions suggests that environmental forcing alone does not control terminus position change, although we note that our use of environmental datasets collected $85-300 \mathrm{~km}$ from the study glaciers might mask any links to near-field conditions. We hypothesize that terminus geometry (ice thickness, subglacial topography, fjord bathymetry) also exerts an important influence on the response of marine-terminating glaciers to environmental perturbations. The response time of a calving terminus to environmental forcing may depend on how quickly it approaches flotation, which itself depends on the ice thickness and water depth as well as the magnitude of the forcing being applied. Models for predicting outlet glacier response to climate change need to include this complex interaction between geometry and environmental forcing.

Our detailed time series points to the problem of characterizing multi-annual glacier behavior on the basis of snapshot observations of terminus position (e.g. Stearns and others, 2005; Howat and others, 2010; Box and Decker, 2011). Isolated observations are unlikely to capture net glacier change because the timing of the transition from retreat to advance for any given glacier is highly variable from year to year.

\section{ACKNOWLEDGEMENTS}

We thank two anonymous reviewers and the scientific editor, Ginny Catania, for constructive comments that helped improve the manuscript. This work was supported by the US National Science Foundation (ANS0710891) and NASA (NNX08AD38G).

\section{REFERENCES}

Amundson JM, Fahnestock M, Truffer M, Brown J, Lüthi MP and Motyka RJ (2010) Ice mélange dynamics and implications for terminus stability, Jakobshavn Isbræ, Greenland. J. Geophys. Res., 115(F1), F01005 (doi: 10.1029/2009JF001405)

Bersch M, Yashayaev I and Koltermann KP (2007) Recent changes of the thermohaline circulation in the subpolar North Atlantic. Ocean Dyn., 57(3), 223-235 (doi: 10.1007/s10236-007-0104-7)

Bevan SL, Murray T, Luckman AJ, Hanna E and Huybrechts P (2012) Stable dynamics in a Greenland tidewater glacier over 26 years despite reported thinning. Ann. Glaciol., 53(60 Pt 2), 241-248 (doi: 10.3189/2012AoG60A076)

Box JE and Decker DT (2011) Greenland marine-terminating glacier area changes: 2000-2010. Ann. Glaciol., 52(59), 91-98 (doi: 10.3189/172756411799096312)

Box JE, Yang L, Bromwich DH and Bai L-S (2009) Greenland ice sheet surface air temperature variability: 1840-2007. J. Climate, 22(14), 4029-4049 (doi: 10.1175/2009JCLI2816.1)

Cappelen J ed. (2012) Weather and climate data from Greenland 1958-2011. DMI Tech. Rep. 12-15. Danish Meteorological Institute, Copenhagen

Dietrich R and 6 others (2007) Jakobshavn Isbræ, West Greenland: flow velocities and tidal interaction of the front area from 2004 field observations. J. Geophys. Res., 112(F3), F03S21 (doi: 10.1029/2006JF000601)

Echelmeyer KA, Harrison WD, Larsen C and Mitchell JE (1994) The role of the margins in the dynamics of an active ice stream. J. Glaciol., 40(136), 527-538

Hanna $E$ and 8 others (2008) Increased runoff from melt from the Greenland ice sheet: a response to global warming. J. Climate, 21(2), 331-341

Hock R (2003) Temperature index melt modelling in mountain areas. J. Hydrol., 282(1-4), 104-115 (doi: 10.1016/S00221694(03)00257-9)

Howat IM, Joughin I, Tulaczyk S and Gogineni S (2005) Rapid retreat and acceleration of Helheim Glacier, East Greenland. Geophys. Res. Lett., 32(22), L22502 (doi: 10.1029/ 2005GL024737)

Howat IM, Joughin IR and Scambos TA (2007) Rapid changes in ice discharge from Greenland outlet glaciers. Science, 315(5818), 1559-1561 (doi: 10.1126/science.1138478)

Howat IM, Joughin I, Fahnestock M, Smith BE and Scambos T (2008) Synchronous retreat and acceleration of southeast Greenland outlet glaciers 2000-2006: ice dynamics and 
coupling to climate. J. Glaciol., 54(187), 646-660 (doi: 10.3189/002214308786570908)

Howat IM, Box JE, Ahn Y, Herrington A and McFadden EM (2010) Seasonal variability in the dynamics of marine-terminating outlet glaciers in Greenland. J. Glaciol., 56(198), 601-613 (doi: 10.3189/002214310793146232)

Joughin I, Abdalati W and Fahnestock MA (2004) Large fluctuations in speed on Greenland's Jakobshavn Isbræ glacier. Nature, 432(7017), 608-610 (doi: 10.1038/nature03130)

Joughin I and 8 others (2008a) Ice-front variation and tidewater behavior on Helheim and Kangerdlugssuaq Glaciers, Greenland. J. Geophys. Res., 113(F1), F01004 (doi: 10.1029/ 2007JF000837)

Joughin I and 7 others (2008b) Continued evolution of Jakobshavn Isbrae following its rapid speed-up. J. Geophys. Res., 113(F4), F04006 (doi: 10.1029/2008JF001023)

Joughin I, Das SB, King MA, Smith BE, Howat IM and Moon T (2008c) Seasonal speed-up along the western flank of the Greenland ice sheet. Science, 320(5877), 781-783 (doi: 10.1126/science.1153288)

Luckman A and Murray T (2005) Seasonal variation in velocity before retreat of Jacobshavn Isbræ, Greenland. Geophys. Res. Lett., 32(8), L08501 (doi: 10.1029/2005GL022519)

Luckman A, Murray T, De Lange R and Hanna E (2006) Rapid and synchronous ice-dynamic changes in East Greenland. Geophys. Res. Lett., 33(3), L03503 (doi: 10.1029/2005GL025428)

McFadden EM, Howat IM, Joughin I, Smith BE and Ahn Y (2011) Changes in the dynamics of marine-terminating outlet glaciers in West Greenland (2000-2009). J. Geophys. Res., 116(F2), F02022 (doi: 10.1029/2010JF001757)

Meier MF and Post A (1987) Fast tidewater glaciers. J. Geophys. Res., 92(B9), 9051-9058 (doi: 10.1029/JB092iB09p09051)

Moon T and Joughin I (2008) Changes in ice front position on Greenland's outlet glaciers from 1992 to 2007. J. Geophys. Res., 113(F2), F02022 (doi: 10.1029/2007JF000927)

Moon T, Joughin I, Smith B and Howat I (2012) 21st-century evolution of Greenland outlet glacier velocities. Science, 336(6081), 576-578 (doi: 10.1126/science.1219985)

Nettles M and 12 others (2008) Step-wise changes in glacier flow speed coincide with calving and glacial earthquakes at Helheim Glacier, Greenland. Geophys. Res. Lett., 35(24), L24503 (doi: 10.1029/2008GL036127)

Nick FM and Oerlemans J (2006) Dynamics of tidewater glaciers: comparison of three models. J. Glaciol., 52(177), 183-190 (doi: 10.3189/172756506781828755)

Nick FM, Vieli A, Howat IM and Joughin I (2009) Large-scale changes in Greenland outlet glacier dynamics triggered at the terminus. Nature Geosci., 2(2), 110-114 (doi: 10.1038/ngeo394)

Pearce AF, Prata AJ and Manning CR (1989) Comparison of NOAA/ AVHRR-2 sea surface temperatures with surface measurements in coastal waters. Int. J. Remote Sens., 10(1), 37-52 (doi: 10.1080/01431168908903846)

Post A, O'Neel S, Motyka RJ and Streveler G (2011) A complex relationship between calving glaciers and climate. Eos, 97(37), 305-306 (doi: 10.1029/2011EO370001)

Pritchard HD, Arthern RJ, Vaughan DG and Edwards LA (2009) Extensive dynamic thinning on the margins of the Greenland and Antarctic ice sheets. Nature, 461(7266), 971-975 (doi: 10.1038/nature08471)

Reeh N, Thomsen HH, Higgins AK and Weidick A (2001) Sea ice and the stability of north and northeast Greenland floating glaciers. Ann. Glaciol., 33, 474-480 (doi: 10.3189/ 172756401781818554)

Rignot E and Kanagaratnam P (2006) Changes in the velocity structure of the Greenland ice sheet. Science, 311(5673), 986-990 (doi: 10.1126/science.1121381)

Rignot E, Box JE, Burgess E and Hanna E (2008) Mass balance of the Greenland ice sheet from 1958 to 2007. Geophys. Res. Lett., 35(20), L20502 (doi: 10.1029/2008GL035417)

Rignot E, Velicogna I, Van den Broeke MR, Monaghan A and Lenaerts J (2011) Acceleration of the contribution of the Greenland and Antarctic ice sheets to sea level rise. Geophys. Res. Lett., 38(5), L05503 (doi: 10.1029/2011GL046583)

Seale A, Christoffersen P, Mugford RI and O'Leary M (2011) Ocean forcing of the Greenland ice sheet: calving fronts and patterns of retreat identified by automatic satellite monitoring of eastern outlet glaciers. J. Geophys. Res., 116(F3), F03013 (doi: 10.1029/ 2010JF001847)

Sohn HG, Jezek KC and Van der Veen CJ (1998) Jakobshavn Glacier, West Greenland: 30 years of spaceborne observations. Geophys. Res. Lett., 25(14), 2699-2702 (doi: 10.1029/98GL01973)

Stearns LA and Hamilton GS (2007) Rapid volume loss from two East Greenland outlet glaciers quantified using repeat stereo satellite imagery. Geophys. Res. Lett., 34(5), L05503 (doi: 10.1029/2006GL028982)

Stearns LA, Hamilton GS and Reeh N (2005) Multi-decadal record of ice dynamics on Daugaard Jensen Gletscher, East Greenland, from satellite imagery and terrestrial measurements. Ann. Glaciol., 42, 53-58 (doi: 10.3189/172756405781812565)

Straneo F and 8 others (2012) Characteristics of ocean waters reaching Greenland's glaciers. Ann. Glaciol., 53(60 Pt 2), 202-210 (doi: 10.3189/2012AoG60A059)

Sutherland DA, Straneo F, Stenson GB, Davidson FJM, Hammill MO and Rosing-Asvid A (2013) Atlantic water variability on the SE Greenland continental shelf and its relationship to SST and bathymetry. J. Geophys. Res., 118(C2), 847-855 (doi: 10.1029/ 2012JC008354)

Thomas RH (2004) Force-perturbation analysis of recent thinning and acceleration of Jakobshavn Isbræ, Greenland. J. Glaciol., 50(168), 57-66 (doi: 10.3189/172756504781830321)

Van der Veen CJ (2007) Fracture propagation as means of rapidly transferring surface meltwater to the base of glaciers. Geophys. Res. Lett., 34(1), L01501 (doi: 10.1029/2006GL028385)

Vieli A and Nick FM (2011) Understanding and modelling rapid dynamic changes of tidewater outlet glaciers: issues and implications. Surv. Geophys., 32(4-5), 437-458 (doi: 10.1007/ s10712-011-9132-4)

Walsh KM, Howat IM, Ahn Y and Enderlin EM (2012) Changes in the marine-terminating glaciers of central east Greenland, 2000-2010. Cryosphere, 6(1), 211-220 (doi: 10.5194/tc-6211-2012)

Walter J and 6 others (2012) Oceanic mechanical forcing of a marine-terminating Greenland glacier. Ann. Glaciol., 53(60 Pt 2), 181-192 (doi: 10.3189/2012AoG60A083) 